\title{
INCULCATE CRITICAL THINKING SKILLS IN PRIMARY SCHOOLS
}

\section{Salvina Wahyu Prameswari, Suharno, Sarwanto}

Universitas Sebelas Maret

salvinawepe@gmail.com

\section{Article History}

accepted 09/07/2018

approved 01/08/2018

published 17/09/2018

\section{Keywords}

skills, critical thinking, elementary school

\begin{abstract}
This paper aims to describe the inculcation of critical thinking skills in primary schools. Critical thinking is a complex thinking process that is thinking in a reflective, independent manner and aims to make reasonable decisions, which include analyzing, synthesizing, recognizing problems and solving them, concluding and evaluating. Critical thinking skills in primary school is still not maximal because the teacher still has not triggered the students to think critically. This research uses descriptive qualitative method with literature study data collection techniques. Based on literature review, it can be concluded that critical thinking skills is a high-level thinking process that needs to be instilled since students in elementary school.
\end{abstract}

Social, Humanities, and Education Studies (SHEs): Conference Series

p-ISSN 2620-9284 https://jurnal.uns.ac.id/shes

e-ISSN 2620-9292 


\section{PENDAHULUAN}

Kemampuan berpikir kritis merupakan kemampuan berpikir dalam tingkat tinggi dalam memecahkan masalah secara sistematis. Menurut pendapat Johnson (2010: 187) kemampuan berpikir kritis merupakan kemampuan berpikir dengan baik, dan merenungkan tentang proses berpikir merupakan bagian dari berpikir dengan baik. Kemampuan berpikir kritis perlu dikembangkan sejak peserta didik duduk di bangku sekolah dasar. Karena kemampuan berpikir kritis harus diasah sejak dini agar siswa terbiasa dengan pola berpikir yang kritis dan kreatif.

Kemampuan berpikir kritis termasuk kemampuan berpikir yang esensial dan berfungsi di semua aspek kehidupan. Menurut Krulik \& Rudnick (dalam Siswono, 2011) secara umum, keterampilan berpikir terdiri atas empat tingkat, yaitu: menghafal (recall thinking), dasar (basic thinking), kritis (critical thinking) dan kreatif (creative thinking). Tingkat berpikir paling rendah adalah keterampilan menghafal (recall thinking) yang terdiri atas keterampilan yang hampir otomatis atau refleksif. Tingkat berpikir selanjutnya adalah keterampilan dasar (basic thinking).

Menurut Facione (2013: 5) aspek kemampuan berpikir kritis terdari dari 6 aspek, yaitu interpretasi (interpretation), analisis (analysis), kesimpulan (inference), evaluasi (evaluation), penjelasan (explanation), dan pengaturan diri (self-regulation). Dengan keenam aspek tersebut, maka kemampuan berpikir kritis siswa akan lebih terarah dan maksimal. Keenam aspek tersebut tidak langsung diajarkan kepada siswa secara keseluruhan, namun dapat dilatihkan secara bertahap sejak dini agar siswa lebih terampil dalam kemampuan berpikir kritisnya di jenjang sekolah yang lebih tinggi.

Kemampuan berpikir kritis sangat penting diterapkan bersama dengan kurikulum 2013. Dimana dalam kurikulum 2013 siswa dituntut untuk aktif dalam proses pembelajaran dan menempatkan guru hanya sebagai fasilitator. Namun kenyataannya, masih banyak siswa yang belum terasah kemampuan berpikir kritisnya dikarenakan guru belum menanamkan kemampuan berpikir kritis kepada siswa. Untuk menanamkan kemampuan berpikir kritis siswa di sekolah dasar, guru dapat berusaha untuk menerapkan model/metode/strategi/ pendekatan pembelajaran yang bervariatif dan inovatif agar siswa lebih tertarik dan termotivasi untuk mengikuti pembelajaran.

Apabila guru telah menerapkan model/metode/strategi/pendekatan pembelajaran yang dapat mengasah kemampuan berpikir kritis siswa maka tujuan pembelajaran akan lebih mudah tercapai secara maksimal. Pembelajaran tidak hanya singgah sebentar di memori siswa namun akan tertanam di memori siswa hingga siswa dewasa.

\section{Hakikat Berpikir}

\section{PEMBAHASAN}

Gilmer dalam Kuswana (2011: 2) berpendapat bahwa berpikir merupakan suatu pemecahan masalah dan proses penggunaan gagasan atau lambang-lambang pengganti suatu aktivitas yang tampak secara fisik. Selanjutnya, Sfard (2009) menyatakan definisi tentang berpikir yaitu, "thinking is a primary process that unfolds naturally "from inside" the person". Berpikir adalah proses utama yang terjadi dalam diri seseorang secara alami.

Berpikir sebagai suatu kemampuan mental seseorang dapat dibedakan menjadi beberapa jenis antara lain berpikir logis, analitis, sistematis, kritis, dan kreatif. Hal yang menjadi perhatian berpikir tingkat tinggi adalah apa yang dilakukan terhadap fakta. Siswa harus memahami fakta, menghubungkan fakta satu dengan fakta yang lainnya mengkategorikan, memanipulasi, menggunakannya bersama situasi yang baru dan menerapkannya dalam mencari pemecahan baru terhadap masalah baru.

Menurut ahli psikologi Gestalt yang dikutip oleh Ngalim Purwanto (1992 : 46), berpikir merupakan keaktifan psikis yang abstrak, yang prosesnya tidak dapat diamati dengan alat indra kita. Sehubungan dengan pendapat para ahli psikologi gestalt, maka 
ahli-ahli psikologi sekarang berpendapat bahwa proses berpikir pada taraf yang tinggi pada umumnya melalui tahapan-tahapan yaitu 1) timbulnya masalah, kesulitan yang harus dipecahkan, 2) mencari dan mengumpulkan fakta-fakta yang dianggap ada sangkut pautnya dengan pemecahan masalah, 3) taraf pengolahan atau pencernaan, fakta diolah dan dicernakan 4) taraf penemuan atau pemahaman, menemukan cara memecahkan masalah, 5) menilai, menyempurnakan dan mencocokkan hasil pemecahan.

Sejalan dengan itu, Harlinda (2014: 6) mendefinisikan bahwa berpikir merupakan suatu usaha yang menggunakan daya nalarnya untuk mengolah informasi dari luar maupun dalam diri seseorang untuk menyelesaikan suatu masalah. Sedangkan Glass dan Holyoak (dalam Suharnan, 2005: 280) mendefinisikan berpikir sebagai proses menghasilkan representasi mental yang baru melalui transformasi informasi yang melibatkan interaksi secara kompleks antara atributatribut mental seperti penilaian, abstraksi, penalaran, imaginasi, dan pemecahan masalah.

Dapat disimpulkan bahwa berpikir adalah proses yang melibatkan interaksi secara kompleks antara atribut-atribut mental seperti penilaian, abstraksi, penalaran, dan imaginasi dalam usahanya untuk memecahkan masalah yang prosesnya tidak dapat diamati secara fisik.

\section{Hakikat Berpikir Kritis}

Berpikir kritis merupakan salah satu tahapan berpikir tingkat tinggi. Costa (Liliasari, 2000: 136) mengkategorikan proses berpikir kompleks atau berpikir tingkat tinggi kedalam empat kelompok yang meliputi pemecahan masalah (problem solving), pengambilan keputusan (decision making), berpikir kritis (critical thinking), dan berpikir kreatif (creative thinking). Berpikir kritis sangat penting dalam kehidupan sehari-hari di masyarakat. Berpikir kritis diperlukan untuk memecahkan masalah yang ada secara rasional dan menentukan keputusan yang tepat dalam waktu yang singkat.

Sejalan dengan itu, Jumaisyaroh, dkk (2015: 88) berpendapat bahwa kemampuan berpikir kritis matematis adalah suatu kecakapan berpikir secara efektif yang dapat membantu seseorang untuk membuat, mengevaluasi, serta mengambil keputusan tentang apa yang diyakini atau dilakukan.

Krulik dan Rudnick (dalam Sabandar, 2007: 3) mengemukakan bahwa, "yang termasuk berpikir kritis dalam matematika adalah berpikir yang menguji, mempertanyakan, menghubungkan, mengevaluasi semua aspek yang ada dalam suatu situasi ataupun suatu masalah". Menurut pendapat di atas, berpikir kritis merupakan proses berpikir dengan cara menganalisis permasalahan kemudian mengambil kesimpulan dengan tepat. Siswa yang sudah terbiasa diasah kemampuan berpikir kritisnya akan lebih peka dan tanggap dalam mengahadapi permasalah yang ada.

Menurut Angelo (1995) "berpikir kritis adalah mengaplikasikan rasional, kegiatan berpikir yang tinggi, yang meliputi kegiatan menganalisis, mensintesis, mengenal permasalahan dan pemecahannya, menyimpulkan dan mengevaluasi". Berdasarkan definisi tersebut, dapat dikatakan bahwa berpikir kritis merupakan suatu rangkaian tahapan untuk mencapai suatu tujuan. Berpikir kritis merupakan bentuk berpikir yang perlu dikembangkan dalam rangka memecahkan masalah, merumuskan kesimpulan, mengumpulkan berbagai kemungkinan, dan membuat keputusan ketika menggunakan semua keterampilan tersebut secara efektif dalam konteks dan tipe yang tepat.

Ricahrd Paul dalam Kowiyah (2012: 176) memberikan definisi bahwa "critical thinking is that mode of thinking - about any subject, content or problem - in which the thinker improves the quality of his or her thinking by skillfully taking change of the structure inherent in thinking and imposing intelectual standards upon them." Dari pendapat Facione dapat dijelaskan bahwa berpikir kritis adalah jenis 
berpikir tentang subjek, konten atau permasalahan, dimana pemikir meningkatkan

kualitas dari kemampuan berpikir mereka dengan merubah struktur berpikir mereka.

berikut:

Sedangkan Harlinda (2014: 8) berpendapat tentang berpikir kritis sebagai

"Berpikir kritis adalah berpikir yang menggunakan akal pikirnya untuk menyelesaikan suatu masalah dengan terlebih dahulu memahami masalah, mengemukakan pendapat atau argumen secara jelas, dapat mendeteksi bias dari berbagai sudaut pandang dan dapat menarik kesimpulan dari permasalahan yang ada."

Dapat disimpulkan bahwa berpikir kritis adalah suatu proses berpikir kompleks yaitu berpikir secara logis dan bertujuan untuk membuat keputusan-keputusan yang masuk akal, melalui proses ilmiah yang sistematis meliputi kegiatan menganalisis, mensintesis, mengenal permasalahan dan pemecahannya, menyimpulkan dan mengevaluasi.

\section{Aspek-aspek Kemampuan Berpikir Kritis}

Aspek-aspek berpikir kritis menurut Facione (2013: 5) terdapat 6 aspek, yaitu: interpretation (interpretasi), analysis (analisis), evaluation (evaluasi), inference (kesimpulan), explanation (penjelasan), and self-regulation (pengaturan diri). Untik lebih jelas akan dipaparkan dalam tabel 1.1 sebagai berikut:

\section{Tabel 1 Aspek Berpikir Kritis}

\begin{tabular}{|c|c|}
\hline Kemampuan & Penjelasan \\
\hline $\begin{array}{l}\text { Interpretation } \\
\text { (interpretasi) }\end{array}$ & $\begin{array}{l}\text { Kemampuan untuk memahami serta mengetahui arti atau maksud dari } \\
\text { suatu pengalaman yang bervariasi, situasi, data, peristiwa, keputusan, } \\
\text { konvensi, kepercayaan, aturan, prosedur, atau kriteria. }\end{array}$ \\
\hline $\begin{array}{l}\text { Analysis } \\
\text { (analisis) }\end{array}$ & $\begin{array}{l}\text { Kemampuan untuk mengidentifikasi maksud dan hubungan yang tepat } \\
\text { antar pernyataan, pertanyaan, konsep, deskripsi, atau bentuk } \\
\text { pertanyaan lain untuk menyatakan kepercayaan, keputusan, } \\
\text { pengalaman, alasan, informasi, atau opini. }\end{array}$ \\
\hline $\begin{array}{l}\text { Evaluation } \\
\text { (evaluasi) }\end{array}$ & $\begin{array}{l}\text { Kemampuan untuk menilai kredibilitas dari suatu pernyataan arau } \\
\text { penyajian lain dengan menilai atau memberi gambaran mengenai } \\
\text { persepsi seseorang, pengalaman, situasi, keputusan, kepercayaan, } \\
\text { atau opini; serta untuk menilai kekuatan logika dari hubungan } \\
\text { inferensial antara pernyataan, deskripsi, pertanyaan, atau penyajian } \\
\text { lain. }\end{array}$ \\
\hline $\begin{array}{c}\text { Inference } \\
\text { (kesimpulan) }\end{array}$ & $\begin{array}{l}\text { Kemampuan untuk mengidentifikasi dan memilih unsur-unsur yang } \\
\text { diperlukan untuk membuat kesimpulan yang beralasan; untuk mmbuat } \\
\text { hipotesis yang beralasan; untuk memperhatikan informasi yang } \\
\text { relevan serta mengurangi konsekuensi yang ditimbulkan dari data, } \\
\text { pernyataan, prinsip, bukti, penilaian, kepercayaan, opini, konsep, } \\
\text { deskripsi, pertanyaan, atau penyajian lain. }\end{array}$ \\
\hline $\begin{array}{l}\text { Explanation } \\
\text { (penjelasan) }\end{array}$ & $\begin{array}{l}\text { Kemampuan untuk menyatakan hasil dari proses seseorang, } \\
\text { kemampuan untuk membenarkan suatu alasan berdasarkan bukti, } \\
\text { konsep, metodologi, kriteria, dan kriteria tertentu yang masuk akal; } \\
\text { serta untuk menjelaskan alasan seseorang dengan argumentasi yang } \\
\text { meyakinkan. }\end{array}$ \\
\hline $\begin{array}{l}\text { Self-regulation } \\
\text { (penguatan diri) }\end{array}$ & $\begin{array}{l}\text { Kesadaran seseorang untuk memonitori aktivitasnya sendiri, elemen- } \\
\text { elemen yang digunakan serta hasil yang dikembangkan dengan } \\
\text { menerapkan kemampuan dalam melakukan analisis dan evaluasi } \\
\text { terhadap kemampuan diri sendiri dalam pengambilan keputusan } \\
\text { dengan bentuk pertanyaan, konfirmasi, validasi, atau koreksi. }\end{array}$ \\
\hline
\end{tabular}
Sumber: Facione (2013:5) 


\section{Tahap-tahap Kemampuan Berpikir Kritis}

Dari pendapat Ennis dalam Amri (2010: 64) menjelaskan bahwa tahap-tahap dalam berpikir kritis adalah sebagai berikut:

a. Fokus (focus). Langkah awal dari berpikir kritis adalah mengidentifikasi masalah dengan baik. Permasalahan yang menjadi fokus bisa terdapat dalam kesimpulan sebuah argumen.

b. Alasan (Reason). Apakah alasan-alasan yang diberikan logis atau tidak untuk disimpulkan seperti yang tercantum dalam fokus.

c. Kesimpulan (Inference). Jika alasannya tepat, apakah alasan itu cukup untuk sampai pada kesimpulan yang diberikan?

d. Situasi (Situation). Mencocokkan dengan situasi yang sebenarnya.

e. Kejelasan (Clarity). Harus ada kejelasan mengenai istilah-istilah yang dipakai dalam argumen tersebut sehingga tidak terjadi kesalahan dalam membuat kesimpulan.

f. Tinjauan ulang (Overview). Artinya kita perlu mencek apa yang sudah ditemukan, diputuskan, diperhatikan, dipelajari dan disimpulkan.

\section{Faktor-faktor yang Mempengaruhi Berpikir Kritis}

Beberpa faktor yang mempengaruhi kemampuan berpikir kritis siswa adalah sebagai berikut:

a. Kondisi fisik

Menurut Sajoto (1990: 16) kondisi fisik adalah satu kesatuan utuh dari komponenkomponen yang tidak dapat dipisahkan begitu saja, baik peningkatan maupun pemeliharaannya. Apabila kondisi siswa terganggu, maka akan berpengaruh pada kemampuan berpikir siswa. Konsentrasi siswa akan menurun dan semangat belajarnya menjadi berkurang.

b. Motivasi

Mariska, dkk (2013: 160) berpendapat bahwa motivasi merupakan dorongan yang ada didalam diri seseorang untuk berusaha mengadakan perubahan tingkah laku yang lebih baik dalam memenuhi kebutuhan. Menurut Juniar (2016: 60) mengatakan bahwa "In simple terms, motivation deals with the questions of why people choose to do an activity over another, how much energy and effort they will be putting in to do the activity and how long they will continue to do the activity". Yang berarti bahwa motivasi erat kaitannya dengan alasan mengapa siswa melakukan kegiatan tersebut.

Dari beberapa pendapat di atas dapat ditarik kesimpulan, memotivasi siswa dapat menumbuhkan minat belajar siswa, dengan tumbuhnya minat belajar siswa maka tujuan pembelajaran dapat tercapai dengan mudah. Dengan diberikan motivasi juga dapat mempermudah guru untuk menyampaikan bahan pengajaran karena minat belajar siswa sudah tumbuh.

c. Kecemasan

Kecemasan merupakan keadaan emosional seseorang terhadap suatu kemungkinan yang dapat membahayan dirinya atau orang lain. Menurut Frued dalam Riasmini (2000) kecemasan timbul secara otomatis jika individu menerima stimulus berlebih yang melampaui untuk menanganinya (internal, eksternal). Reaksi terhadap kecemasan dapat bersifat; a) konstruktif, memotivasi individu untuk belajar dan mengadakan perubahan terutama perubahan perasaan tidak nyaman, serta terfokus pada kelangsungan hidup; b) destruktif, menimbulkan tingkah laku maladaptif dan disfungsi yang menyangkut kecemasan berat atau panik serta dapat membatasi seseorang dalam berpikir.

d. Perkembangan intelektual

Tingkat perkembangan intelektual siswa berbeda antara satu siswa dengan yang lain. Ada beberapa faktor yang mempengaruhi perkembangan intelektual siswa. 
Perkembangan intelektual juga dipengaruhi oleh usia dari siswa itu sendiri. Menurut Piaget dalam Purwanto (1999) semakin bertambah umur anak, semakin tampak jelas kecenderungan dalam kematangan proses.

e. Interaksi

Rath et. al. (dalam Himawan, 2014: 42) menyatakan bahwa salah satu faktor yang dapat mempengaruhi perkembangan kemampuan berpikir kritis adalah interaksi antara pengajar dan siswa. Suasana pembelajaran yang kondusif akan meningkatkan semangat siswa dalam proses pembelajaran sehingga siswa dapat berkonsentrasi dalam memecahkan masalah yang diberikan.

\section{Karakteristik Berpikir Kritis}

a. Watak

Bayer (1995: 12-15) menjelaskan karakteristik berpikir kritis sebagai berikut:

Seseorang yang mempunyai keterampilan berpikir kritis mempunyai sikap skeptis, sangat terbuka, menghargai sebuah kejujuran, respek terhadap berbagai data dan pendapat, respek terhadap kejelasan dan ketelitian, mencari pandanganpandangan lain yang berbeda, dan akan berubah sikap ketika terdapat sebuah pendapat yang dianggapnya baik.

b. Kriteria

Dalam berpikir kritis harus mempunyai sebuah kriteria atau patokan. Untuk sampai ke arah sana maka harus menemukan sesuatu untuk diputuskan atau dipercayai. Meskipun sebuah argumen dapat disusun dari beberapa sumber pelajaran, namun akan mempunyai kriteria yang berbeda. Apabila kita akan menerapkan standarisasi maka haruslah berdasarkan kepada relevansi, keakuratan fakta-fakta, berlandaskan sumber yang kredibel, teliti, tidak bias, bebas dari logika yang keliru, logika yang konsisten, dan pertimbangan yang matang.

c. Argumen

Argumen adalah pernyataan atau proposisi yang dilandasi oleh data-data. Keterampilan berpikir kritis akan meliputi kegiatan pengenalan, penilaian, dan menyusun argumen.

d. Pertimbangan atau pemikiran

Yaitu kemampuan untuk merangkum kesimpulan dari satu atau beberapa premis. Prosesnya akan meliputi kegiatan menguji hubungan antara beberapa pernyataan atau data.

e. Sudut pandang (point of view)

Sudut pandang adalah cara memandang atau menafsirkan dunia ini, yang akan menentukan konstruksi makna. Seseorang yang berpikir dengan kritis akan memandang sebuah fenomena dari berbagai sudut pandang yang berbeda.

f. Prosedur penerapan kriteria (procedures for applying criteria)

Prosedur penerapan berpikir kritis sangat kompleks dan prosedural. Prosedur tersebut akan meliputi merumuskan permasalahan, menentukan keputusan yang akan diambil, dan mengidentifikasi perkiraan-perkiraan.

\section{Manfaat Berpikir Kritis}

Menurut April (2015) manfaat berpikir kritis dijabarkan seperti di bawah ini:

a. Memiliki banyak alternatif jawaban dan ide kreatif

Dimana Anda juga akan dapat berpikir secara mandiri dan reflektif. Berpikir dan bertindak reflektif adalah tindakan dan pikiran yang tidak Anda rencanakan, terjadi secara spontan dan begitu saja secara refleks.. Terbiasa berpikir kritis juga akan membuat Anda memiliki banyak alternatif jawaban serta ide-ide kreatif. Jika Anda mempunyai suatu masalah, Anda tidak hanya terpaku pada satu jalan keluar atau penyelesaian, Anda akan memiliki banyak opsi atau pilihan penyelesaian masalah tersebut. Berpikir kritis akan membuat Anda memiliki banyak ide-ide kreatif dan inovatif serta out of the box. 
b. Mudah memahami sudut pandang orang lain

Berpikir kritis membuat pikiran dan otak Anda lebih fleksibel. Anda tidak akan terlalu kaku dalam berpikir atas pendapat atau ide-ide dari orang lain. Anda lebih mudah untuk menerima pendapat orang lain dan persepsi yang berbeda dari persepsi Anda sendiri. Hal ini memang tidak mudah untuk dilakukan, namun jika Anda telah terbiasa untuk berpikir kritis, maka dengan sendirinya, secara spontanitas, hal ini akan mudah untuk Anda lakukan.

c. Menjadi rekan kerja yang baik

Lebih banyak manfaat-manfaat lain yang bisa Anda peroleh karena berpikir kritis. Dan manfaat-manfaat itu pada umumnya saling berkaitan. Misalnya saja Anda lebih mudah, terbuka, menerima, serta tidak kaku dalam menerima pendapat orang lain, Anda tentu kaan lebih dihormati oleh rekan kerja Anda. Karena Anda mau menerima pendapat orang lain dengan pikiran terbuka. Maka rekan kerja Anda pasti akan menganggap Anda sebagai rekan kerja yang baik. Di dalam lingkungan kerja, hal lain yang penting selain pekerjaan dan hubungan dengan atasan adalah lingkungan kerja.

d. Lebih Mandiri

Berpikir kritis membuat Anda mampu berpikir lebih mandiri, artinya tidak harus selalu mengandalkan orang lain. Saat dihadapkan pada situasi yang rumit dan sulit serta harus segera mengambil keputusan, Anda tidak perlu menunggu seseorang yang Anda anggap mampu menyelesaikan masalah, karena Anda sendiri juga mampu menyelesaikan masalah tersebut. Dengan memiliki pikiran yang kritis, Anda dapat memunculkan ide-ide, gagasan, serta saran-saran penyelesaian masalah yang baik. Dengan berpikir kritis, akan melatih otak Anda untuk berpikir lebih kritis, tajam, kreatif, serta inovatif.

e. Sering menemukan peluang baru

Dengan berpikir kritis, lebih memungkinkan Anda untuk menemukan peluangpeluang baru dalam segala hal, bisa dalam pekerjaan maupun bisnis atau usaha Anda. Berpikir kritis membuat pikiran Anda lebih tajam dalam menganalisa suatu masalah atau keadaan. Tentu saja hal ini akan berdampak pada kewaspadaan Anda itu sendiri. Untuk menemukan peluang, dibutuhkan pikiran yang tajam serta mampu menganalisa peluang yang ada pada suatu keadaan. Berpikir kritis akan menguntungkan Anda, karena Anda akan lebih cepat dalam menemukan peluang tersebut jika dibandingkan dengan orang yang tidak terbiasa berpikir kritis.

f. Meminimalkan salah persepsi

Salah persepsi akan sering terjadi bila Anda tidak terbiasa berpikir kritis. Saat Anda menerima sebuah pernyataan dari orang lain dan orang lain tersebut juga percaya akan pernyataan tersebut maka jika Anda memiliki pemikiran yang kritis Anda akan mencari kebenaran akan persepsi tersebut. Anda tidak akan mudah salah dalam sebuah persepsi yang belum tentu benar hanya dengan orang lain mengatakan hal tersebut adalah benar. Saat Anda tahu sebuah persepsi dari orang lain tersebut salah Anda akan membantu bukan hanya diri Anda tapi juga orang tersebut. Dengan semakin Anda berpikir kritis hal ini akan meminimalkan salah persepsi.

g. Tidak mudah ditipu

Berpikir kritis membuat Anda dapat berpikir lebih rasional serta beralasan. Anda mengambil keputusan berdasarkan fakta, atau Anda akan menganalisa suatu anggapan terlebih dahulu kemudian Anda kaitkan dengan sebuah fakta. Anda tidak mudah percaya dengan perkataan orang lain. Sehingga hal tersebut akan memudahkan Anda untuk tidak tertipu atau ditipu oleh orang lain. Anda akan memproses suatu informasi apakah relevan atau sesuatu yang mustahil sehingga Anda dapat simpulkan sebagai sesuatu yang tidak benar atau mengandung unsur kebohongan. 


\section{Penerapan Kemampuan Berpikir Kritis di Sekolah Dasar}

Menurut Bonnie dan Potts (2003) secara singkat dapat disimpulkan bahwa beberapa "ciri khas" pembelajaran berpikir kritis meliputi: (1) Meningkatkan interaksi antar siswa, (2) Dengan mengajukan pertanyaan open-ended, (3) Memberikan waktu yang memadai kepada siswa untuk memberikan refleksi terhadap pertanyaan yang diajukan atau masalah-masalah yang diberikan, dan (4) Teaching for transfer (Mengajar untuk dapat menggunakan kemampuan yang baru saja diperoleh terhadap situasi-situasi lain dan terhadap pengalaman sendiri yang para siswa miliki). Kegiatan yang dapat mengembangkan keterampilan berpikir kritis siswa adalah denganmenjawab pertanyaan-pertanyaan inovatif: Adakah Cara lain? (What's another way?), Bagaimana jika...? (What if ...?), Manakah yang salah? (What's wrong?), dan Apakah yang akan dilakukan? (What would you do?) (Krulik \& Rudnick, 1999).

a. Adakah cara lain?

Dalam pertanyaan dibuat kondisi soal tetap, tidak berubah kemudian fokuskan pada problem, serta siswa diminta untuk mengerjakan soal tersebut dengan cara lain. Hal ini dapat melatih ketrampilan berpikir kritis pada siswa.

Misalnya: Andi memiliki 300 buah apel. Keseluruhan apel akan dimasukkan ke dalam 15 kantong kain. Berapa apel pada masing-masing kantong? Apakah ada cara lain untuk menyelesaikan permasalahan Andi?

b. Bagaimana jika...?

Dalam pertanyaan ini apabila kondisi soal berubah maka berpengaruh pada jawaban soal, kemudian siswa menganalisis soal yang berubah tersebut. Hal ini melatih ketrampilan berpikir kritis pada siswa.

Misalnya: Dalam sebuah kotak terdapat 6 kelereng merah, 4 kelereng biru, dan 3 kelereng kuning. Pada pengambilan pertama secara acak diperoleh bola biru dan tidak dikembalikan. Tentukan peluang terambilnya bola merah pada pengambilan kedua?

Jawaban : $\mathrm{P}(\mathrm{M})=$

Kemudian ajukan pertanyaan Bagaimana jika bola biru pada pengambilan pertama dikembalikan? Berapa peluang terambilnya bola merah pada pengambilan kedua?

c. Manakah yang salah?

Dalam pertanyaan ini Disajikan soal dan jawabannya, tetapi jawaban tersebut memuat kesalahan misalnya pada konsep atau perhitungan kemudian siswa diminta mencari kesalahan, memperbaiki, menjelaskan, dan memperbaiki. Hal ini dapat melatih ketrampilan berpikir kritis pada siswa.

d. Apakah yang akan dilakukan?

Setelah menyelesaikan, siswa diminta membuat keputusan misalnya lewat gagasan atau pengalaman pribadi siswa, kemudian siswa juga harus menjelaskan dasar keputusannya. Hal ini dapat melatih ketrampilan berpikir kritis.

Misalnya: Akum ditawari oleh temannya untuk memilih salah satu dari dua minuman ringan. Minuman yang pertama dengan merk " $A$ " berbentuk tabung dengan jari-jari $7 \mathrm{~cm}$ dan tinggi $17 \mathrm{~cm}$. Minuman yang kedua dengan merk "B" berbentuk balok dengan berukuran $4 \mathrm{~cm} \times 4 \mathrm{~cm} \times 15 \mathrm{~cm}$. Minuman merk apa yang harus Andi pilih? Mengapa?

\section{SIMPULAN}

Kemampuan berpikir kritis akan membekali siswa agar mampu memecahkan permasalah yang dihadapinya secara logis dan sistematis. Berpikir kritis akan berguna bagi segala aspek kehidupan. Sekolah dasar sebagai lembaga pendidikan pertama bagi anak sangat penting untuk mulai menanamkan kemampuan berpikir kritis siswa. Melatih kemampuan berpikir kritis siswa dapat dipadukan dengan penggunaan model/media/strategi/pendekatan pembelajaran yang memancing kemampuan berpikir kritis siswa secara merata. Oleh karena itu, guru dituntut untuk kreatif dan inovatif 
dalam menyusun pembelajaran yang menyenangkan agar siswa tertarik dan termotivasi untuk mengikuti pembelajaran.

\section{DAFTAR PUSTAKA}

Amri, S. (2010). Proses Pembelajaran Kreatif dan Inovatif dalam Kelas. Jakarta. PT Prestasi Pustakaraya. Jakarta.

Angelo, Thomas A. \& Cross, Patricia (1995). Classroom Assessment Techniques: A Handbook for College Teachers, 2nd edition

Bonnie dan Potts. (2003). Strategies for Teaching Critical Thinking. Practical Assesment, Research \& Evaluation. [online]. Tersedia: http $: / /$ edresearch.org/pare/getvn.asp? $\mathrm{v}=4 \& \mathrm{n}=3$

Facione. (2013). Critical Thinking: What It Is and Why It Counts. Millbrae, CA: Measured Reasons and The California Academic Press.

Fatmawati, Harlinda. (2014). Analisis Berpikir Kritis Siswa Dalam Pemecahan Masalah Matematika Berdasarkan Polya Pada Pokok Bahasan Persamaan Kuadrat (Penelitian Dilakukan Di Smk Muhammadiyah 1 Sragen Tahun Ajaran 2013/2014). Skripsi: UNS.

Himawan, Ivan. (2014). Kontribusi Persepsi Tentang Pemanfaatan Media Pembelajaran dan Kemampuan Berpikir Kritis Terhadap Prestasi Belajar Sejarah Siswa Kelas X di SMA Negeri 1 Ngemplak Boyolali Tahun Ajaran 2012/2013. Skripsi: UNS

Johnson, T. E., Archibald, T. N., \& Tenenbaum, G. (2010). Individual and team annotation effects on students' reading comprehension, critical thinking, and meta-cognitive skills. Computers in Human Behavior, 26, 1496-1507.

Jumaisyaroh, T., Napitupulu, E. E., \& Hasratuddin. (2015). Peningkatan Kemampuan Berpikir Kritis Matematis dan Kemandirian Belajar Siswa SMP melalui Pembelajran Berbasis Masalah. Jurnal AdMathEdu 5(1), 87-106.

Juniar, Rima. (2016). The Role of Motivation in Learning English for Indonesian Students. International Journal of Management and Applied Science Volume-2, Issue-8, ISSN: 2394-7926

Kowiyah. (2012). Kemampuan Berpikir Kritis. Jurnal Pendidikan Dasar Vol. 3, No. 5

Krulik, S \& Rudnick. (1999)."Innovative Taks to Improve Critical and Creative Thinking Skills. Develoving Mathematical Raesoning in Grades K-12', pp.138-145.

Kuswana, Wowo Sunaryo.(2011). Taksonomi Berpikir. Bandung: PT Remaja Rosdakarya

Liliasari. (2000). Model Pembelajaran untuk Meningkatkan Keterampilan Berpikir Konseptual Tingkat Tinggi Calon Guru IPA. Dalam Proceeding Nasional Science Education Seminar, The Problem of Mathematics and Science Education and Alternative to Solve the Problems. Malang: JICAIMSTEP FMIPA UM

M. Sajoto. (1990). Peningkatan \& Pembinaan Kekuatan Kondisi Fisik Dalam Olahraga. Jakarta: Dahara Prize

Mariska, dkk. (2013). Efektivitas Pemberian Apersepsi dan Motivasi dalam Meningkatkan Pemahaman Konsep Siswa pada Pokok Bahasan Gaya SMP Negeri 13 Purworejo. Jurnal Radiasi Vol. 3 No. 2.

Ngalim Purwanto. (1992). Psikologi Pendidikan. Bandung: Remaja Rosdakarya Offset.

Riasmini. (2000). Pengembangan Berpikir Kritis dalam Pembelajaran Sejarah. Skripsi: UNJ

Sabandar, J. (2007). Berpikir Reflektif. Makalah disampaikan pada Seminar Nasional Sehari: Permasalahan Matematika dan Pendidikan Matematika Terkini tanggal 8 Desember 2007. UPI Bandung: Tidak Diterbitkan

Siswono, T. Y. E. 2011. Level of student's creative thinking in classroom mathematics. Journal Educational Research and Review. Vol. 6, No. 7, pp 548-553.

Suharnan. (2005). Psikologi Kognitif. Surabaya: Srikandi. 